This item was submitted to Loughborough's Research Repository by the author.

Items in Figshare are protected by copyright, with all rights reserved, unless otherwise indicated.

\title{
The green economy: Reconceptualizing the natural commons as natural capital
}

PLEASE CITE THE PUBLISHED VERSION

https://doi.org/10.1080/17524032.2015.1018296

\section{PUBLISHER}

(C) Taylor and Francis

\section{VERSION}

AM (Accepted Manuscript)

\section{PUBLISHER STATEMENT}

This work is made available according to the conditions of the Creative Commons Attribution-NonCommercialNoDerivatives 4.0 International (CC BY-NC-ND 4.0) licence. Full details of this licence are available at: https://creativecommons.org/licenses/by-nc-nd/4.0/

\section{LICENCE}

CC BY-NC-ND 4.0

\section{REPOSITORY RECORD}

Boehnert, Joanna. 2019. "The Green Economy: Reconceptualizing the Natural Commons as Natural Capital”. figshare. https://hdl.handle.net/2134/35077. 


\section{The Green Economy: \\ Re-Conceptualizing the Natural Commons as Natural Capital}

\section{Joanna Boehnert}

The green economy is an emergent approach to sustainable development launched at Rio+20. Herein environmental decision-making is increasingly achieved through economistic processes and logic. The natural commons is quantified and managed as natural capital. This paper summarizes the trajectory of the project and its ideological framework. It examines various conceptualizations of economic approaches to the environment and considers philosophical, methodological and political problems associated with the green economy project. In the face of very different definitions of what constitutes a green economy, environmental communicators face a situation characterized by discursive confusion as the complexity of natural capital accounting processes conceal new political configurations. Counter-movements argue that the green economy program is performing ideological work that uses the language of the environmentalism to obscure an intensified agenda of neoliberal governance and capital accumulation. The concept now has contradictory meanings. Environmental communicators have an important role to play in exposing the contested nature of the project and in helping to define the emerging green economy.

Key words: green economy; commons; ecological economics; natural capital; neoliberalism

This paper will be published in late March 2015 in the journal Environmental Communication at this link: http://dx.doi.org/10.1080/17524032.2015.1018296. 
The green economy project was launched June 2012 at Rio +20 by the United Nations Environment Program (UNEP) with their flagship document titled Towards a Green Economy: Pathways to Sustainable Development and Poverty Eradication (2011). The project presents itself as a far-reaching program of reform. While the rhetoric suggests that the UN is serious about addressing the biodiversity crisis, green economists and a wide variety of social movements were less convinced by the proposed policy mechanisms. Civil society responded at Rio +20 with a plethora of critical responses: condemning what they claimed amounted to the corporate capture of the United Nations (UN) (Joint Civil Society Statement, 2012); condemning the "Natural Capital Declaration" (Banktrack, 2012); condemning 20 years of Greenwash (Bruno, 2012); and indeed, condemning the entire green economy project (Nadal, 2012; Brand, 2012a; Patel \& Crook, 2012). The Indigenous People's Global Conference on Rio+20 and Mother Earth (2012) issued a strongly worded "Kari-Oca 2 Declaration" (2012) describing UNEP's green economy as "a continuation of colonialism" (p. 1) and firmly rejecting market-based solutions, REDD (Reducing Emissions from Deforestation and forest Degradation) and intellectual property rights over genetic resources and traditional knowledge. In the wake of the polarized positions at Rio +20 , the conference ended with both civil society and the UN unimpressed with the outcomes. The New York Times claimed Rio+20 "ended here as it began, under a shroud of withering criticism" (Romero \& Broder, 2012); The Guardian's headline read: "Rio+20 outcome a focal point for frustration among campaigners" (Ford, 2012); and the Financial Times announced "Rio+20 lacks ambition, says UN chief" (Clark, 2012). The conference failed to achieve binding targets but more significantly the conference launched UNEP's green economy project which aims to redesign the processes through which the global commons will be managed. What is noteworthy about this is the degree to which environmental language is used to advance a project that is ideologically antithetical to many of the environmental movement's basic premises. UNEP's green economy is a fiercely contested concept rejected by indigenous groups, social movements and NGOs concerned with both environmental conservation and environmental justice.

In naming its program the "green economy", UNEP and partners imply a reframing of the entire economy along green lines. The language even suggests a connection to a particular school of economic thought concerned with the environment, that of green economics. However, the program itself reflects policy prescriptions of other schools of economic thinking on the environment, namely environmental economics and to a lesser degree, ecological economics. Since green economics is a field with very different policy prescriptions to what is proposed, the naming of the new project creates a situation characterized by discursive confusion. In this paper, the 
"green economy project" will be referred to as "GEP" to avoid confusion with what green economists have been describing as "green economics" for at least fifteen years.

This paper will examine the development of the concept of a green economy and situate the GEP in relation to different economic approaches to the environment. It will compare various types of green economic theory and demonstrate how the GEP blurs these distinctions. In an attempt to clarify competing discourses it will examine specific philosophical, methodological, and political problems with the GEP. It will also reflect on risks and suggest strategies for communicating the contested nature of the GEP proposal. While the GEP is in the process of becoming hegemonic (in the UK especially), "there is as yet no agreed definition of what constitutes a green economy" (Stakeholders Forum, 2012, paragraph 1). It is possible to describe the ideological framework of the GEP and a few of the ways in which this idea has been developed, as described in the "Towards a Green Economy" UNEP report (2011) for example. The GEP project has many aspects (agriculture, water, forests, fisheries, renewable energy, manufacturing, waste, buildings, transport, tourism, cities) and policy recommendations vary for each. Analysis of the specific policy proposals for any these sectors is beyond the scope of this paper which will focus on the ideological work that buttresses the project, the ways in which this ideology is being presented as if it were neutral, and associated communication issues.

Since the green economy is still being defined, environmental communication plays a key role in constructing what is understood as a green economy while also drawing attention to the power dynamics, motivations and economic interests of institutional actors. An example of this work exposing corporate power and the GEP is the "Who will Control the Green Economy?" (2011) report by the ETC Group (Action Group on Erosion, Technology and Concentration). The GEP relies on the use of environmental language and concepts such as "green economy", "natural capital" and “ecosystem services". Environmental communicators are in a good position to clarify the providence of these terms and reveal how new meanings are being created.

\section{Introduction to the Green Economy Project}

The GEP is part of a political project wherein environmental decision-making is shifting from political governance processes to economistic processes and logic. With this change, environmental concerns, concepts and language are used to describe policy 
agendas where markets determine environmental priorities. Despite the green rhetoric, critics claim that the GEP will give more control and power to the corporate and the financial sectors to manage nature through natural capital accounting processes. Thus in stark opposition to what green economists have traditionally conceived of as the green economy, with its emphasis on democratic decision-making, the GEP moves environmental decision-making out of the public sphere and into the marketplace.

Decisions about the environment will be made by those with the capital to participate in these markets.

While undoubtedly most scientists and environmentalists involved with the GEP aim to find a means of helping/making political and economic actors to acknowledge the value of the environment, submitting nature to the logic of the market (and the financial industry) is an extraordinarily dangerous enterprise. Instead, green economic theory asserts that the economic system must submit to the logic of the ecological systems that provides the geophysical context for economic systems to exist in the first place. By using the term "green economics" the GEP obscures the differences between different ways of managing the ecological commons, i.e. a natural commons based approach (i.e. green economics) versus a natural capital based approach (i.e. environmental economics). This obscuring process is probably not, in the vast majority of cases, a deliberate strategy by the individuals involved. Environmentalists working on the GEP are disillusioned with the current approach (which is clearly not working to protect biodiversity) and see the project as a means of securing funding for conservation (Newey, 2014). Yet vested interests are masked behind a politics that insists that the market is a neutral playing field.

The GEP aims to protect nature by accounting for externalities of environmental damage. According to this logic, once nature's processes are given a financial value, prices of goods and services will reflect ecological costs and it will no longer make economic sense to produce ecologically harmful products or degrade environmental spaces. The project relies on the assumption that nature's processes can be safely disaggregated and effectively managed using natural capital accounting. While there are other elements of the GEP (some of which are commendable), this paper focuses on the monetarization and market-making policy prescriptions. The financial valuation policies are the most significant aspect of the program since other proposals will be subordinated to the economic logic of these modes of governance. Ultimately, the GEP relies on the 
private sector for investment and in exchange for capital investment ownership and control will be granted to private corporations and financial institutions. A whole new range of financial products will be created based on "natural capital". This will create lucrative opportunities for the financial sector with new markets for speculation. Expectations of profits will drive these new markets while environmental rhetoric provides convenient green marketing and public relations messaging to conceal continued - and indeed amplified unsustainable development.

\section{Etymology of the green economy, natural capital and ecosystem services}

The term "green economy" was first coined in the Blueprint for a Green Economy (1989) report by Pearce, Markandya, and Barbier (Allen \& Clouth, 2012, p. 7). In a paper titled "Green economy - The next oxymoron? No lessons learned from failures of implementing sustainable development" Brand (2012b) claims that "the concept of a green economy is, like sustainable development, rather an oxymoron which intends to bundle different, partly contradictory, interests and strategies and gives them a certain legitimacy and coherence" (p.2). The project is an amalgamation of conflicting agendas. On the one hand, it is a desperate attempt by scientists and environmentalists to convince industrialists and politicians to prioritize environmental concerns. On the other hand, it is the recognition by business of opportunities for profit in the creation of new green markets. The first section of UNEP's report (2011) is titled "From crisis to opportunity". The word "opportunity" is used 87 times throughout the document. In the context of the GEP, the notion of new business opportunities refers to new profits derived, to a substantial degree, from a new model of private ownership of the natural commons. This process will be facilitated by governments who in some cases (the UK) are already creating the infrastructure to sell the rights to the environment under the pretext that by conceptualizing the non-human natural world as natural capital corporate executives will be motivated to make responsible decisions.

The GEP has emerged from the development of the two foundational concepts: "natural capital" and "ecosystem services". Figure One illustrates the relationship between ecosystem science, ecosystem services, and ecosystem markets by illustrating the role of capital in the intellectual construction of this framework. The two concepts are examined below. 


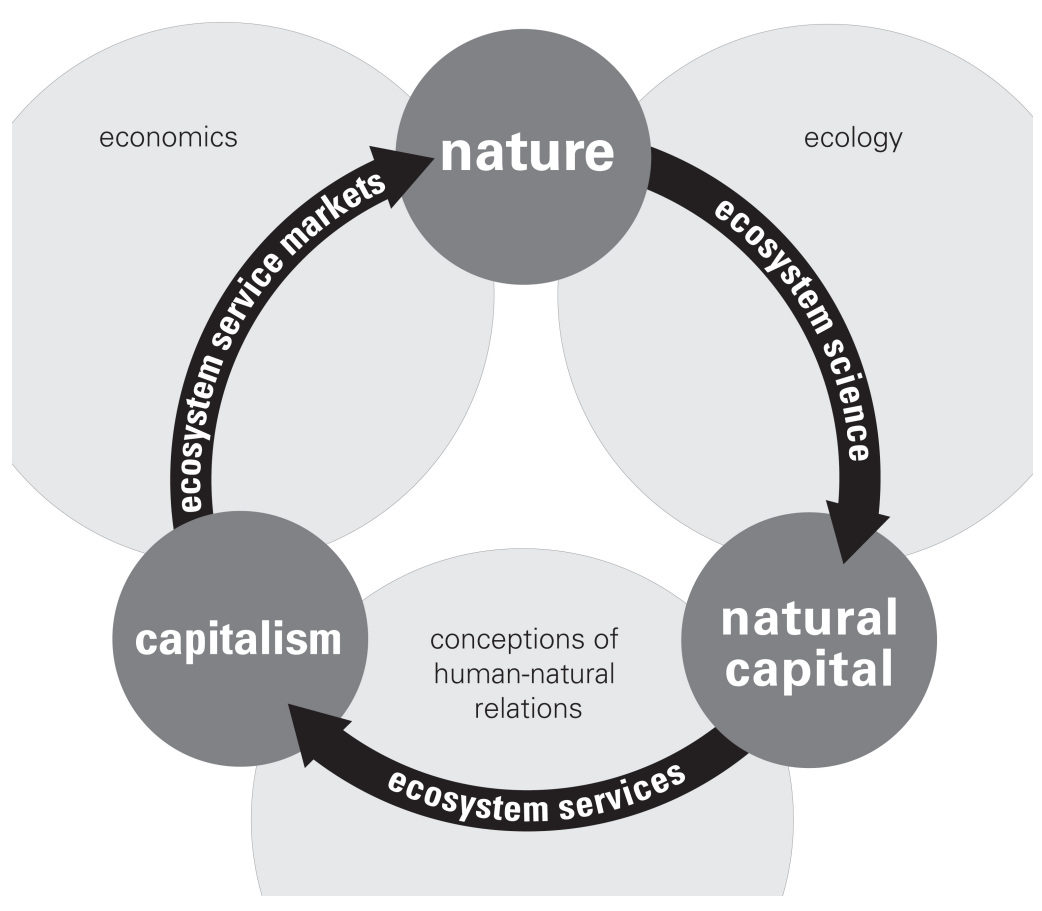

Figure 1. The Theory of Natural Capital and Ecosystem Services $(\mathrm{C}$ EcoLabs (2014).

\section{Natural capital}

E.F. Schumacher first used the concept of natural capital in his book Small Is Beautiful (1973, p. 2). Sullivan (2013b) describes the current meaning of the concept of natural capital as having its origins in the formation of the World Business Council for Sustainable Development (WBCSD) at the first Rio United Nations Conference on Environment and Development (UNCED) Earth Summit in 1992. In a popular 1994 speech, WBCSD's Maurice Strong said, “addressing the challenge of achieving global sustainability, we must apply the basic principles of business. This means running 'Earth Incorporated' with a depreciation, amortization and maintenance account"' (Strong, paragraph 42). The concept of natural capital gained popularity in business circles as a way of thinking about environmental governance and was encouraged by environmentalists such as Paul Hawken, Amory Lovins, Hunter Lovins and Jonathan Porritt. Now, four decades since the concept was first coined, the idea has metamorphosed. The notion of nature as natural capital, and as equivalent to capital in the bank, is being adopted by national governments. In 2011, UK Environment Minister Caroline Spelman launched the report "The natural choice: Securing the value of nature” with the statement, “...if we withdraw something from Mother Nature's Bank, we've got to put something back to ensure that the environment has a healthy balance 
and a secure future" (paragraph 8). In 2012 the UK established a Natural Capital Committee and economists began "preparing to include a value for 'natural capital' in Britain's GDP calculations by 2020, a move that promises to be the greatest change in national accounting practices since their creation 70 years ago" (Whipple, 2012, paragraph 2). Meanwhile, at an international level, the Bank of Natural Capital website was launched in 2011 by The Economics of Ecosystems and Biodiversity (TEEB) project, a project supported by the UN and European Union (EU). Within the Bank of Natural Capital "nature's stocks and flows are depicted such that they accord with the format of a standard online current bank account” (Sullivan, 2013b, paragraph 13). Nature's processes are reduced to capital that can be traded like other financial instruments.

This conceptualization of the natural world as natural capital has deep reaching implications. Sullivan (2013b) describes natural capital as involving four types of shifts: a discursive shift; a material shift; a calculative and accounting shift; and an institutional shift. This kind of comprehensive treatment would be commendable if the management of economic affairs was to be changed in keeping with the needs and logic of ecological processes. Instead, the management of environmental issues will be conducted using economic logic and financial instruments. The concept of natural capital gained traction at Rio+20 where 40 CEOs of banks, investors and insurers signed the "Natural Capital Declaration", launched by UNEP's Finance Initiative. This project has been gaining strength, especially in the UK, a nation whose economy is heavily dependent on the financial industry. The World Forum on Natural Capital was held in Edinburgh in November 2013 (see below).

\section{Ecosystem services}

The concept of an ecosystem was first used in 1935 by Arthur Tansley. The theory of ecosystem services was not used until the 1980s and 1990s (Costanza et al., 1997; Dempsey \& Roberston, 2012) and not formalized until the publication of the United Nations 2005 Millennium Ecosystem Assessment. Today applications of the concept: "include its use as a communication tool, for policy guidance and priority setting, and for designing economic instruments for conservation" (Luck et al., 2012, p.1020). There are four types of ecosystem services: provisioning services (producing food, fuel, and fiber); regulation services (the maintenance of the climate, regulation of floods and 
diseases, biological control of pest populations, pollination of crops, and filtration and purification of water); cultural services (benefits to science such as pharmaceutical products or spiritual, educational, and recreational benefits); and supporting services enabling all the above (nutrient cycling and the creation of soil, etc.) (DEFRA, 2007). The concept of ecosystem services is a powerful idea that covers all kinds of natural processes.

While the concept of ecosystem services can be a useful learning tool, the reduction of ecology into services that are helpful to humans instrumentalizes ecological relations. This becomes a problem especially when ecosystem services are used as a component of market processes as opposed to the context in which markets are enabled to exist. Today's largest ecosystem services market is the EU Emissions Trading Scheme (ETS) designed to reduce carbon emission. Lohmann (2011) describes how the ecosystem service concept has been used here: "the first step was to simplify and quantify the ecological functions in question, so that standardized increments of 'environmental improvement' could be traded for standardized bits of 'environmental destruction"” (p. 2). Unfortunately, gross carbon emissions have not been reduced by the EU ETS, although it has worked to enable polluting industries to profit from selling permits (Gilbertson \& Reyes, 2009). Within the GEP, the concept of ecosystem services facilitates the creation of markets for a wide variety of ecological processes, but the example of the EU ETS does not bode well for the use of market mechanisms as a means of protecting the natural world. Lohmann (2012) claims climate negotiations have been derailed by monetization and financialization and asserts that this same strategy is now being applied to biodiversity loss with the GEP.

Both natural capital and ecosystem services can be understood as what Brendon Larson describes as feedback metaphors in environmental sciences. A feedback metaphor "harbours social values [that] circulate back into society to bolster those very values" (Larson, 2011, p. 22). These two concepts emphasize an instrumental, utilitarian and fragmenting approach to the natural world. While they function well within neoliberal modes of governance, this way of understanding the natural world is deeply problematic. Both concepts reinforce a perspective wherein the environment is reduced to a part of the economic system. As powerful metaphors functioning as part of the GEP, these ideas threatens to transform our relationship to the non-human natural world 
by asserting that clean air, water, and habitats for endangered species are privileges (Adams, 1996, p.100) rather than a commons that all of humanity shares.

\section{Varieties of Economic Approaches to the Environment}

Environmental economics, ecological economics, green economics and eco-socialist economics are distinct discourses with different conceptualizations of the relationship between the environment and the economy. They have different policy prescriptions that relate especially to the degree to which they believe market mechanisms can help with the management of environmental problems. All too often economics in conservation discourses is conflated with the ideological assumptions of neoliberalism (Buscher et al., 2012, p.5), as if this is only type of economic policy is that is viable.

The GEP follows the theory of environmental economics (such as David Pearce) and, to a lesser extent, ecological economics (such as Robert Costanza). It attempts to preserve biodiversity by factoring environmental externalities into economics, creating processes for valuation and trading of two particular externalities: destruction and pollution. Environmental economics uses market mechanisms and valuation as a corollary of "normal" economics and values things, including ecosystems, in monetary terms. Both environmental and ecological economics attempt to account for the geophysical context by using the concept of environmental externalities. Ecological valuation processes enable environmental and ecological economics to use marketbased mechanisms as a means of decision-making for the environment. It is worth noting that monetary valuation of nature is still contested by some prominent ecological economists. For example, Herman Daly recently (2013) updated an earlier paper with the statement:

Witness economists' attempts to value species by asking consumers how much they would be willing to pay to save a threatened species, or how much they would accept in compensation for the species' disappearance. The fact that the two methods of this "contingent valuation" give different answers only adds comic relief to the underlying tragedy, which is the reduction of value to taste weighted by income (paragraph 13).

While monetization processes are contested within the field of ecological economics, green economics rejects the monetization of nature entirely. Green economics also 
opposes the use of the concept of environmental externalities and the notion of substitutability.

Green economics is distinct from the GEP. According to green economists, both environmental and ecological economics make too many concessions to the reductive logic of neoclassical and neoliberal economics. Green economists such as Molly Scott Cato, Mary Mellor, Hazel Henderson, Richard Douthwaite, James Robertson, and Andrew Simms treat the environment as the overarching system and one that is best understood as a commons. In Green Economics: An Introduction to Theory, Policy and Practice, Cato (2009) explains that while "green economists accept many of the theoretical conclusions of the ecological economists, especially the importance of ending economic growth and developing a steady-state economy" (p. 206), they reject the neoclassical/environmental economics concept of an "externality". The logic of attempting to make capitalism sustainable by accounting for ecological externalities is dubious according to green economic theory. The UN's own data indicates that none of the world's top industrial sectors would be profitable if environmental costs were fully integrated (Roberts 2013, paragraph 11).

\begin{tabular}{|c|c|c|c|c|c|}
\hline & $\begin{array}{l}\text { neo-classical + } \\
\text { neo-liberal }\end{array}$ & environmental & ecological & $\begin{array}{l}\text { green } \\
\text { economics }\end{array}$ & eco-socialist \\
\hline assumptions & $\begin{array}{l}\text { value-neutral } \\
+ \text { composed } \\
\text { of universal, } \\
\text { unchanging } \\
\text { laws }\end{array}$ & $\begin{array}{l}\text { bringing the } \\
\text { environment } \\
\text { into economic } \\
\text { theory }\end{array}$ & $\begin{array}{l}\text { committed to } \\
\text { steady state } \\
\text { economics }\end{array}$ & $\begin{array}{l}\text { local, social, } \\
\text { political and } \\
\text { qualitative }\end{array}$ & $\begin{array}{l}\text { the market } \\
\text { will always } \\
\text { attempt to } \\
\text { exploit the } \\
\text { environment }\end{array}$ \\
\hline $\begin{array}{l}\text { attitude } \\
\text { towards the } \\
\text { planet }\end{array}$ & $\begin{array}{l}\text { a source } \\
\text { of scarce } \\
\text { resources for } \\
\text { the economy }\end{array}$ & $\begin{array}{l}\text { a source } \\
\text { for scarce } \\
\text { resources } \\
\text { and a sink for } \\
\text { pollution }\end{array}$ & $\begin{array}{l}\text { the system } \\
\text { in which the } \\
\text { economy is a } \\
\text { embedded } \\
\text { (as a subsystem) }\end{array}$ & $\begin{array}{l}\text { the context } \\
\text { of human } \\
\text { existance }\end{array}$ & $\begin{array}{l}\text { the context } \\
\text { of human } \\
\text { existance }\end{array}$ \\
\hline $\begin{array}{l}\text { sees the } \\
\text { environmental } \\
\text { crisis as... }\end{array}$ & $\begin{array}{l}\text { an inconsequential } \\
\text { concern or an } \\
\text { opportunity }\end{array}$ & $\begin{array}{l}\text { a result of } \\
\text { market failure }\end{array}$ & $\begin{array}{l}\text { a result of } \\
\text { regulatory } \\
\text { failure }\end{array}$ & $\begin{array}{l}\text { a result of } \\
\text { the dismissal } \\
\text { of nature }\end{array}$ & $\begin{array}{l}\text { a result of } \\
\text { capitalism }\end{array}$ \\
\hline $\begin{array}{l}\text { principle } \\
\text { concept }\end{array}$ & $\begin{array}{l}\text { efficiency of } \\
\text { markets }\end{array}$ & $\begin{array}{l}\text { scarcity + } \\
\text { efficiency of } \\
\text { markets }\end{array}$ & $\begin{array}{l}\text { precautionary } \\
\text { stance }\end{array}$ & quality & commodity \\
\hline policy impulse & market & market & $\begin{array}{l}\text { regulation / } \\
\text { market }\end{array}$ & $\begin{array}{l}\text { participatory } \\
\text { politics }\end{array}$ & $\begin{array}{l}\text { participatory } \\
\text { politics }\end{array}$ \\
\hline externality & yes & yes & potentially & no & no \\
\hline
\end{tabular}

Figure 2. Economic Approaches to the Environment (C) EcoLabs (2014).

Both ecological and green economists reject the GDP metric as a means of measuring the wellbeing of a nation's economy and both aim to redefine economic prosperity in a 
manner that emphasizes qualitative not quantitative growth (Capra \& Henderson, 2009; Jackson, 2009). Ecological economics supports new metrics, often advocating the Genuine Progress Indicator (GPI) ( Kubiszewski et al., 2013) while green economics aims for qualitative assessment of economic progress that cannot be reduced to a single quantitative metric. Green economics is committed to the primacy of intrinsic value in organizing economic relations, where the objective is the meeting of need rather than generating profit. Green economics rejects the concept of substitutability (the idea that a particular ecosystem can be substituted and accounted for by saving another ecosystem elsewhere).The chart in Figure Two clarifies some of the key differences between various economic approaches to the environment.

\section{Problems for Environmental Communicators}

These divergent definitions of green economy create a serious dilemma for environmental communicators. The task of communicating a set of policy initiatives proposed by the UNEP that are closely related to a neoliberal market liberalization agenda under the banner of the "green economy" creates confusion within environmental discourses. Counter-movements claim that the obscuring rhetoric of the GEP serves the interests of those who want increased free-markets and continued unsustainable development without the interference of environmental regulations. The predicament for environmental communicators is profound. On one hand, there is a need to refer to the GEP by its name - yet the name itself appropriates the language of green economists, thereby creating a discursive obfuscation of the actual policy agenda. Green economists aim to reclaim the concept of a green economy, but in doing so they face the challenge of appearing to support the GEP. Meanwhile scientists and social scientists are busy helping develop the conceptual, scientific, and institutional infrastructure that will support the transition to the GEP. This section will look at philosophical, methodological and political problems associated with the GEP.

\section{Philosophical Issues}

The GEP re-imagines the global commons in a manner that demonstrates a misunderstanding of levels in ecological theory. Environmental and ecological economics hold that natural capital brings the environment onto the balance books of 
industry. For environmental economists, "the environment's first role... is as a supplier of resources" (Hanley, Shogren \& White, 2007, p. 3) and they understand nature as a subsystem of the economy (McAfee, 2012, p.109). This conceptualization is erroneous. The environment is not only a supplier of resources, but it is the geophysical context that makes the idea of resources even possible. Ecological economists recognize this concept in theory, but in practice they also reduce the environment to part of the economic system. This error is manifested throughout the new project. The global ecological commons are the source of life and the basis for all activities - economic and non-economic. Economics is a construct made possible by ecological processes. Ecological processes are simply too complex to be captured absolutely through financial valuation processes because they are the context of economics, not a subsystem of economics (as visualized in Figure Three). The GEP is premised on the epistemological error that assumes the economic system is of greater importance than the ecological system on which the economy depends. It is no small thing to bring nature into the space where everything must prove its financial worth (which is not possible for methodological and political reasons described below). Ecological systems are not fragmented, but are complex webs of interconnected and interdependent relations that cannot be effectively understood, much less managed in isolation. Reducing the value of nature to financial terms is an epistemological shift that facilitates exploitation in a material realm. Counter-movements argue that conceptions of the natural world as subject to the logic of the market are a prelude to the sale of those environments that are desired by industry for development. 


\section{Conceptions of human-natural relations:}

\section{A hierarchy of systems}

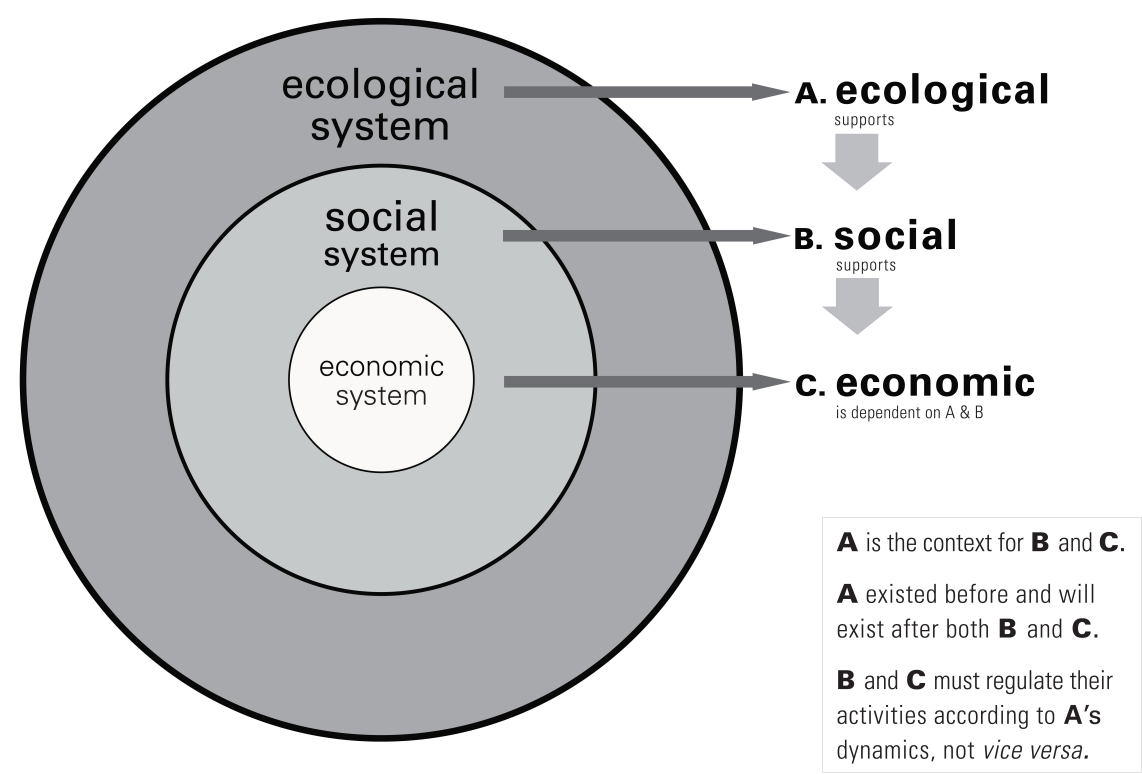

Figure 3. Conceptions of Human-Natural Relations: Hierarchy of Systems $\odot$ EcoLabs (2014).

\section{Methodological Issues}

Philosophical errors spawn further methodological problems in the quantification and monetization of nature's processes. Methodological problems include the limits of scientific capacities to value nature's various processes; the consistent undervaluation of ecosystem services; the underestimation of risk; the issue of substitutability; and issues of communication and motivation. Humankind simply does not have the scientific capacity to measure all of the life-sustaining services provided by nature but what is obvious (to those with even basic ecological literacy) is that there will be no financial system to create wealth without the benefit of a stable climate, clean water and healthy local ecosystems. When scientists do fix a price for nature, these values are often absurdly low, illustrating the practical consequences of logical and epistemological errors. This problem has been evident since Costanza et al. described the average value of the world's ecosystem services and natural capital as \$33trillion/year in 1997 (p.253). While the authors of this seminar paper acknowledge the fact the "economies of the earth would grind to a halt without the services of ecological life support systems" and that there "the many conceptual and empirical problems inherent in producing such an estimate" (p.253), the low valuation set a precedent that has plagued the financialization 
agenda. Clearly Costanza et al. aimed to create a means to prioritize environmental concerns. Unfortunately, within the context of neoliberalization of modes of governance, even strong environmental concepts are appropriated and transformed into new means to support capital accumulation (in this case by obscuring human-nature relations with natural capital accounting processes).

More recently, "The economics of ecosystems and biodiversity (TEEB)" (2010) report uses the estimate of $€ 153$ billion (\$205bn USD) as the total economic value of insect pollination worldwide (p. 8). It is a high number, but does this number actually reflect the value of pollinating insects? Considering that our existence is entirely dependent on ecosystem services - and pollinating insects that are a vital part of these ecosystems - it follows that insects are worth more than a small percentage of the value of total global production (GGDP). Similarly, the Prince's Foundation Accounting for Sustainability Project (2011) published an image that inverts the hierarchy of the relationship between economy and ecology (see Figure Four). This project aims to make a case for sustainability and yet the numbers distort and misrepresent the relationship between the economic and ecological system.

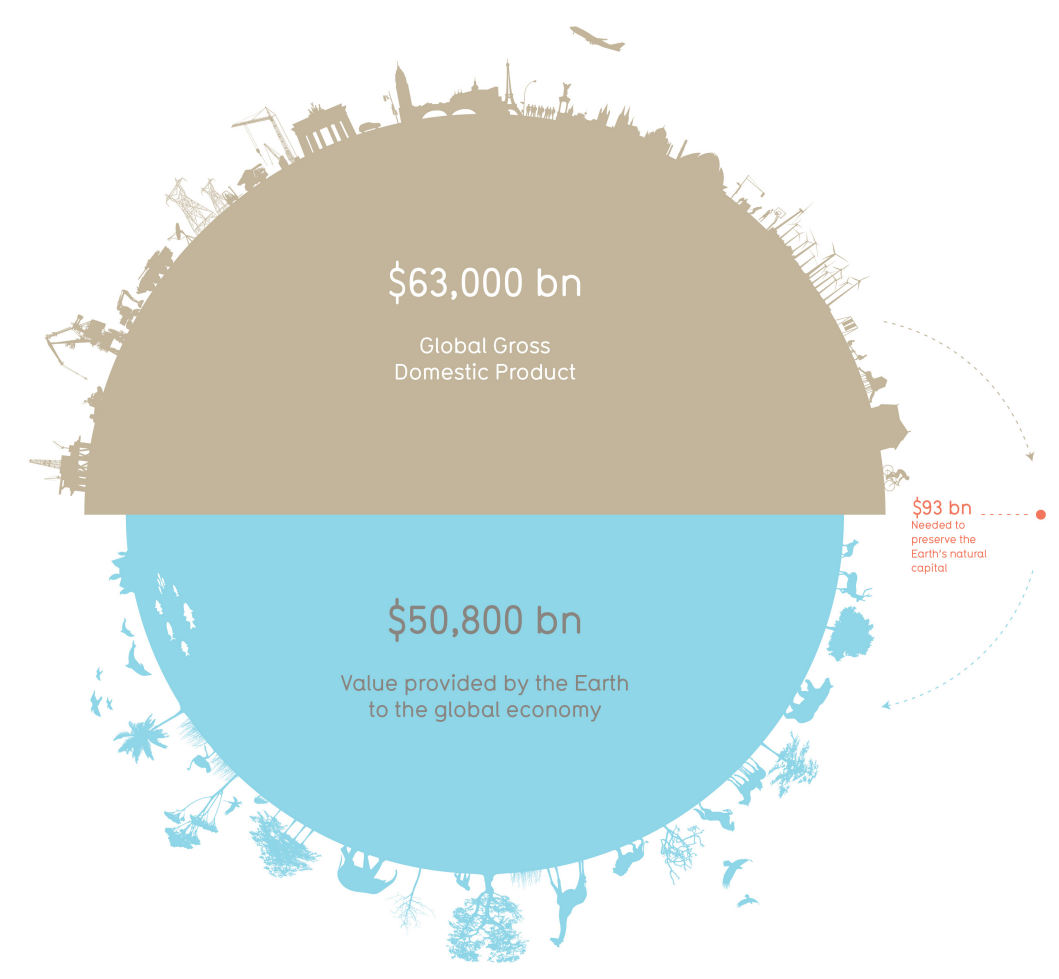

Figure 4. Costing the Earth (C) [Information is Beautiful Studio] (2011). London: The Prince's Accounting for Sustainability. 
While the numbers lend an aura of authority to environmental debates, they fail to establish a truthful framing of humankind's dependence on the natural world. At the World Forum on Natural Capital in Edinburgh, Scotland's First Minister Alex Salmond claimed that nature is worth between $£ 21.5$ to $£ 23$ billion per year to the Scottish economy (World Forum on Natural Capital, 2013, paragraph 7). The valuation is diminutive. Scotland's economy is entirely dependent on the relative stability and provisioning services provided by the environment. When Friends of the Earth UK designed their campaign to protect bees, they used the figure of $£ 1.8$ billion ( $\$ 2.8 \mathrm{bn}$ USD) as the financial value of bees in the UK. Again the numbers represent a reduction of complexity in complex ecosystems and fail to account for the fact that ecological systems have tipping points that trigger abrupt changes and even collapse.

Furthermore, the monetization of nature encourages the underestimation of risk. While market processes give the "impression that humankind can control nature as 'assets' so as to have the possibility to 'bail out' earth systems when they break down" (Fioramonti, 2013, p. 118), once ecological thresholds are passed money cannot fix extinct species, collapsed ecosystems, climate change, etc.. Financial valuation processes reward ignorance on issues of risk since knowledge and value have a corollary relationship, i.e. the higher the level of knowledge of the risks of ecologically damaging activity, the higher the value assigned to ecosystems in cost-benefit analysis (Adams 1996, p.108). Thus financial valuation methodology actually encourages greater ecologically illiteracy as it rewards the denial of risks (by under-valuing ecological spaces and species). Ultimately, the numbers have more to do with politics and power than the value of a particular ecosystem service.

Even if financial valuation processes were to give ecosystem services high monetary value, market-making processes remains inherently problematic due to the assumption of substitutability. Ecosystem markets generate the conditions for development and ruin of individual ecosystem services with the pretext that others will be conserved. With this formulation, the GEP assumes that animals, forests and a stable climate, etc. are somehow replaceable by the wizardry of financial markets. The nonhuman natural world is reconceptualized as natural capital that will be conserved (in order to provide ecosystem services), or sold to enable development (and ensuing ecological degradation). This project does create opportunities for business at first, but once destroyed an ecosystem cannot be fixed or saved by other preserved ecosystems 
elsewhere. Net ecosystem services are diminished.

A final set of methodological problems pertains to communication, identity and psychological motivations. Motivational crowding out theory (Vatn, 2000, 2010) describes how motivation for environmental conservation is impacted by utilitarian logic that risks "eroding noneconomic incentives for environmental stewardship" (Luck et al., 2012, p.1024). The Common Cause project on motivation in strategies for change describes the ways in which human identity and values are encouraged or discouraged through social practices and communication. Framing the environment in monetary terms has profound implications for human-nature relations since it impacts human motivation and agency for change making. Psychological and communication researchers describe how the financial valuation of nature encourages extrinsic values (those centered on external approval or rewards, values such as seeking social status) resulting in a simultaneous erosion of intrinsic values (those that are inherently rewarding, values such as benevolence) (Crompton \& Kasser, 2009; Common Cause, 2014, paragraph 12). Campaigning strategists allege that the utilitarian mindset established by quantification processes pushes out intrinsic values and the strong attachments to nature that have traditionally driven pro-environmental behavior (Crompton, 2013). Cognitive scientists, including George Lakoff (2009), have demonstrated the limitation of quantitative, utilitarian and exclusively rational modes of reasoning in motivation on politicized issues. George Monbiot (2014) summarizes Lakoff's position and describes why it matters for the ways in which we frame humannature relations:

...you cannot win an argument unless you expound your own values and reframe the issue around them. If you adopt the language and values of your opponents "you lose because you are reinforcing their frame." Costing nature tells us that it possesses no inherent value; that it is worthy of protection only when it performs services for us; that it is replaceable. You demoralise and alienate those who love the natural world while reinforcing the values of those who don't.

For Monbiot and other critics of the GEP, environmentalists who accept the economic framing and monetization of nature are "stepping into a trap their opponents have set" (Monbiot, 2014). This framing of the environment establishes a feedback metaphor that reinforces the epistemological error described earlier. 


\section{Political Issues}

Political problems with the GEP include its ruin of democratic participation in environmental decision-making and risks associated with the neoliberalization of environmental policy. Evidence of the democratic failure of the project was evident at Rio+20 where indigenous communities, social movements and NGOs objected to the exclusion of their voices from the GEP policy-making processes. With new ecosystem services markets, democratic control of development agendas will be even more difficult as markets become the spaces where environmental decisions are made. Those making decisions will be those with the financial capacities to participate. Ecosystem services markets can be understood as new means of producing profit (for those with financial capital) from activities that were otherwise not managed through commodity relationship - and a new wave of privatization of the commons.

A growing body of literature on neoliberalization of nature describes its characteristics: financialization, marketization, privatization, deregulation and reregulation (Sullivan 2013a; Arsel \& Buscher 2012; Böhm, Misoczky \& Moog, 2012; Castree, 2008a). Additionally, methods of governmentality are being implemented wherein complexity replaces responsibility and where governments outsource responsibilities for regulation (Castree, 2008a; Peck, 2010). While rolling-back responsibilities of the state, neoliberal governments simultaneously roll-out other types of state functions, creating an "explosion of 'market conforming' regulatory incursions" (Peck, 2010, p. 23). Within a neoliberal context, government policy works to facilitate market processes rather than attend to social or environmental priorities. The relationship between the global economic and financial crises and the emerging GEP has been described in depth by Lohmann (2011, 2012), Sullivan (2012, 2013a), Nadal (2012), Arsel and Buscher (2012) and Food and Water Europe (2012, 2013). According its critics, the GEP is supported by the corporate and financial sectors because they recognize the program an expansion of the scope of market, an intensification of the neoliberal model and an exceptional opportunity to create new financial instruments based on a new type of capital. The GEP also establishes new markets for financial speculation. 
Recent history has seen a transformation in modern capitalism characterized by the rise of financialization, i.e. the increasing importance of "financial motives, financial markets, financial actors and financial institutions in the operation of the domestic and international economies" (Epstein, 2005, p. 3). While the last economic crisis, estimated to cost governments globally at least \$12 trillion (Conway, 2009), demonstrated the fallibility of the financial sector, the GEP brings the logic of financialization to the management of nature. The activist slogan "nature does not to bailouts" responses to this dilemma.

In recent decades market forces have come to exert enormous influence in environmental policy and conservation. The GEP intensifies this trend. Brand and Vardot describe how epistemic selectivities, i.e. "mechanisms inscribed in political institutions which privilege particular forms of knowledge, problem perceptions, and narrative over others" (2013, p.218) are now working toward the valorization of nature, or "the appropriation of nature for its marketing" (p.209). Here instrumental and utilitarian logic is used to privilege economic values, submit nature to this logic and then conceal continued unsustainable development by marketing the process as a green project. Political possibilities outside of market-based options are not considered. The power grab that occurred during the last financial crisis has put the corporate and financial sectors in a strong position to push forward this agenda.

Critics of the GEP claim that its financial valuation and market-creating work creates opportunities for investors to extract greater profit from the management of nature while simultaneously weakening the capacity of political institutions to stop destructive development, especially where governance processes are weaker than market forces. There will be money to be made in new markets but the act of creating markets for natural capital also establishes conditions for natural spaces to be sold. The work of environmental and social scientists supporting the GEP gives scientific authority to the project, but the important decisions will have already been determined. Once the ideological work has been done and mechanisms are established to substitute one ecosystem service for another, this approach provides a means to legitimize the development of critical ecological sites. For example, UK Environment Minister Owen Paterson used the concept of biodiversity offsetting to justify the destruction of old growth forests, with the promise that 100 new trees will be planted for each ancient tree destroyed (The Guardian, 2014, paragraphs 3-4). 
Critics claim that the GEP is a deepening commitment to the neoliberal political project (Buscher et al., 2012; Dempsey \& Robertson, 2012; Lohmann, 2012; Nadal, 2012; Brand, 2012a, 2012b, 2012c; Brand \& Vadrot, 2013). Herein "the subordination of social and environmental considerations to macroeconomic policy imperatives" is normalized (Nadal, 2012, p. 15). Once "macroeconomic objectives are determined, every other policy target is chiseled in accordance" (Nadal, 2012, p. 15). For those who have internalized this logic, there appears to be no alternative. Neoliberalism is characterized by the elevation of market-based principles and techniques of governance to state-endorsed norms (Peck, 2013). This ideology is becoming entrenched in politics and has enabled a dramatic concentration in capital over the past three decades, documented in global wealth and inequality reports (Fuentes-Nieva \& Galasso, 2014). The new political configuration and the lack of regulation have enabled widespread land grabbing and green grabbing (Fairhead, Leach \& Scoones, 2012). Ideology laden policy proposals such as the GEP claim to be politically neutral (UNEP, 2011, p.7) but powerful interests are concealed behind the pretense of the inevitable expansion of capitalist logic, i.e. markets as a means of organizing ever-increasing domains of human existence. Politics that presents itself as non-political (Castree, 2008a, p.143, citing Beck, 2000, p.122) works to naturalize and obscure the interests behind dramatic new political reconfigurations, now using the green economy as one of the most powerful concepts to legitimize an intensified neoliberal political project. The discursive confusion resulting from the use of environmental language to describe a project of market expansion, privatization, neoliberal governance and even violent dispossession serves the interests of those who would not like these dynamics to be clear and who would also like to appear to be doing the right thing by the environment, without disturbing business as usual.

\section{Developments since Rio+20}

Since Rio +20 the GEP project has been developed by UNEP, the UK government, the World Business Council for Sustainable Development, TEEB for Business Coalition and other institutional and organizational actors. While some of this work sets out to help business understand the environmental consequences of their activities, the project continues to be fiercely contested. The World Forum on Natural Capital in Edinburgh in November 2013 was a recent site for ideological and discursive contestation. The event 
described an urgent need for action. Like at Rio+20, based solely on the marketing rhetoric, it appeared to be the type of integrated project environmental movements have attempted to create for decades. The glaring exception was the conference's major sponsor, the Royal Bank of Scotland (RBS), a bank heavily invested in the Canadian Tar Sands project. As the conference progressed the ways in which natural capital accounting can function as a means to greenwash corporate practice became apparent. For example, a representative of mining company Rio Tinto described how natural capital accounting helped them manage their environmental impact. This prompted World Development Movement director Nick Dearden to tweet: "Now \#RioTinto is? telling us about their net positive impact on the world. That's the beauty of natural capital.”(@nickdearden75,2013).Counter movements claim that natural capital accounting also sets the stage for environmental spaces to be sold, a fact that is also recognized by some in the financial industry. Neil Brown, a fund manager and speaker for a session on the role of the financial sector stated: "Once you put a price on nature in order to protect it, you may find someone willing to pay slightly more in order to destroy it" (quoted in CounterBalance, 2013, paragraph 7).

Environmental justice groups protested outside the "The World Forum on Natural Capital" conference and organized a counter-conference called "Nature is Not for Sale: Forum on the Natural Commons". This second event highlighted alternative means of managing the ecological commons, i.e. "food sovereignty, community energy, remunicipalise water. Less finance, more regulation" (@nickdearden75,2013b). A declaration called "No to Biodiversity Offsetting" signed by 150 global organizations was launched. Organizers of the counter-conference exposed the contradictions with the GEP project both at the conference (which as streamed online) and with the Twitter hashtag \#natureforsale.

These two Edinburgh events shed light on the tensions and stratification between the discourses of "natural commons" versus those of "natural capital". The Forum on the Natural Commons used the commons as the point of reference to resist the expansion of market-based environmental decision-making and the reduction of nature to a new form of capital. The World Forum on Natural Capital used the rhetoric and ideology of necessity to attempt to transcend politics and replace accountability with the obscuring complexity of natural capital accounting processes. Scientists and environmentalists are needed to manage complexity and the GEP has proponents in the 
environmental community who see possibilities for new environmental funding schemes. Critics argue that the GEP works primarily to leave corporations to selfregulate, with new tools to conceal continued polluting activities. Rather than holding polluters accountable, natural capital processes give polluters more powerful means to greenwash their activities with "net biodiversity" gains and the ability to buy the rights to natural capital. Since the natural commons are already been used by local (often indigenous) communities, natural capital accounting creates new mechanisms for land and green grabbing. For example, tropical forests are now valued as a potential for carbon storage, biofuel production, a source of REDD funding and as a source of global conservation funding and/or biodiversity offsetting. Those with the financial capital to invest in natural capital (i.e. these forests) all too often do not recognize the rights of indigenous people to share the natural commons. Evictions and dispossessions are a result (Fairhead, Leach \& Scoones, 2012).

\section{Strategies for Environmental Communication}

Green economist and politician Molly Scott Cato (2012) calls on environmental movements to resist the appropriation and redefinition of the term green economy. The problem then becomes: how do environmental communicators even describe the GEP project? The $\mathrm{UN}$ is attempting to define a financial valuation program as the green economy. Clearly it has greater resources to establish cultural legitimacy than relatively marginalized green economists and social movements without such significant institutional support. The confusion is already leading to incoherent public discourses. The rhetorical devices environmental communicators have at their disposal have become contaminated with contradictory meanings. The results are very confusing even for seasoned professionals. It is difficult to talk about a green economy when this expression is used to refer to two entirely different types of deliberations on the commons with contradictory policy proposals. This paper has tactically refused to call the GEP the green economy as a means of differentiating different discourses. Environmental communicators in sympathy with green economists can clumsily deal with this problem by adding "false" or "so-called" in front of every instance of the GEP - but this is a defensive tactic rather than a long-term strategy.

Those of us involved with communicating the interests of the environment must clarify competing discourses, support democratic processes and describe GEP policies 
along with associated risks. Counter movements are exposing these dynamics, yet these critiques remain marginal. Following the analysis presented in this paper, recommended communication strategies are listed here:

- challenge the undervaluation of nature in natural capital accounting

- clarify the different policy agendas of the GEP and those of green economics

- expose the dangers of prioritizing economic profit over environmental conservation

- expose mechanisms which create opportunities for profit, but have ecological risks

- expose closures of deliberations and encourage democratic processes

- expose obfuscation tactics and challenge greenwashing

- expose the appropriation of the language of environmental movements and reclaim it

- engage with a political analysis of the neoliberalization of the environment

- $\quad$ support social movements in their work to describe and build viable alternatives

- support communities impacted by land and green grabbing as a result of the GEP

- draw attention to the violence struggles that emerge in the context of the GEP

Longer-term strategies include building capacity for greater critical ecological literacy so as to enable more profound analysis of environmental problems and the politics that perpetuate weak approaches to sustainable development. Clearly there are alternatives. The BankTrack statement released at Rio +20 proposes:

...instead of expanding the scope of markets to every domain of nature, creating a true green economy would start from the opposite; reversing the tide of commodification and financialization, reducing the role of markets and the financial sector, acknowledging the limits of business versus other spheres of life, and recognizing the collective responsibility of all people for, and strengthening the democratic control over the worlds' ecological commons (2012, p.1).

There is important work to be done in clarifying competing discourses and making it apparent that there are other models for managing the natural commons.

\section{Conclusion}

None of the above should be read to imply that the vast majority of scientists, ecological or environmental economists and others working on the GEP are not sincere in their intentions to use the project to protect the environment. Unfortunately, their analysis is flawed. The GEP is an intensification of the neoliberal political project. It is a new 
phase in the long trajectory of the enclosures of the common. Social and environmental justice campaigners are the first to oppose the GEP because they are aware that marginalized communities will feel the immediate impact. The Indigenous People's Kari-Oca 2 Declaration (2012) describes the UN's GEP as a “continuation of colonialism... a perverse attempt by corporations, extractive industries and governments to cash in on Creation by privatizing, commodifying and selling off the Sacred and all forms of life and the sky" (p.1-2). Re-conceptualizing the entire natural commons as natural capital, where this second term is used to describe non-human nature as commodities that can be traded, is an extraordinarily dangerous proposition for reasons described in this paper.

The man who first coined the idea of natural capital had strong ideas in regards to the use of financial valuation approaches to protect nature. In the same book where the term "natural capital" was first published, E.F. Schumacher (1973) wrote:

To press non-economic values into the framework of the economic Calculus... it is a procedure by which the higher is reduced to the level of the lower and the priceless is given a price. It can therefore never serve to clarify the situation and lead to an enlightened decision. All it can do is lead to self-deception or the deception of others; for to undertake to measure the immeasurable is absurd and constitutes but an elaborate method of moving from preconceived notions to foregone conclusions... The logical absurdity, however, is not the greatest fault of the undertaking: what is worse, and destructive of civilization, is the pretence that everything has a price or, in other words, that money is the highest of all values. (p. 27)

As the concept of natural capital is transformed, the intellectual work of the environmental movement is being used to advance a project negating its ideological foundations. It is incumbent on environmental movements to distinguish the ways in which neoliberalism functions to obscure its own processes by co-opting environmental language. In appropriating the most powerful environmental concepts, neutering these ideas of their content and then using this language to market political projects that support its own aims, the neoliberal political project masks its own dynamics while making it appear as if theirs is a green agenda. Revealing the tensions and obfuscations on issues of the green economy is a substantial task for those of us who believe we will not protect the environment by creating the conditions for it to be sold. 


\section{Acknowledgements}

I am grateful to James Beecher, Luke Devlin, Rebecca Wasil, Max Boykoff and the anonymous reviewers for constructive feedback. I thank the Cooperative Institute for Research in Environmental Sciences at University of Colorado Boulder for financial support.

\section{References}

Accounting for Sustainability. (2012). Valuing natural capital: The economic invisibility of nature images. Retrieved from http://www.accountingforsustainability.org/ embedding-sustainability/theeconomic-invisibility-of-nature-information-is-beautiful-images

Adams, J. (1996). Risk. London: UCL Press.

Allen, C., \& Clouth, S. (2012). A guidebook to the green economy. New York: United Nations Division for Sustainable Development - UNDESA.

Arsel, M., \& Buscher, B. (2012). Nature ${ }^{\mathrm{TM}}$ Inc.: Changes and continuities in neoliberal conservation and market-based environmental policy. Development and Change. $43(1), 53-78$.

Banktrack. (2012). Banktrack: On the natural capital declaration. Rio de Janeiro, Brazil. Retrieved from http://www.banktrack.org/show/news/banktrack _position_on_the_natural_capital_declaration

Beck, U. (2000). What is globalization? Cambridge: Polity.

Bell, S., \& Golledge, A. (2012). Reviving British bees: Why we need a national bee action plan. Retrieved from www.foe.co.uk/resource/briefings/bees_ report_briefing.pdf

Böhm, S, Misoczky, M.C., \& Moog, S. (2012) Greening capitalism? A Marxist critique of carbon markets. Organization Studies, 33 (11), 1617-1638.

Brendon, L. (2011) Metaphors for environmental sustainability: Redefining our relationship with nature. London: Yale University Press.

Brand, U. (2012a). Beautiful green world: On the myths of a green economy. Berlin: Rosa Luxemburg Foundation. Retrieved from http://www.rosalux.de/ publication/38457/beautiful-green-world.html 
Brand, U. (2012b). Green economy - The next oxymoron? No lessons learned from failures of implementing sustainable development. GAIA-Ecological Perspectives for Science and Society, 21 (1). 28-32.

Brand, U. (2012c). Green economy and green capitalism: Some theoretical considerations. Journal für Entwicklungspolitik. 28 (3). 118-137.

Brand, U. \& Vadrot, A.B.M. (2013). Epistemic selectivities and the valorisation of nature: The cases of the Nagoya Protocol and the Intergovernmental SciencePolicy Platform for Biodiversity and Ecosystem Services (IPBES), Law, Environment and Development Journal, 9 (2), 202-222.

Bruno, K. (2012). Greenwash+20. Amsterdam: Greenpeace International. Retrieved from http://www.greenpeace.org/international/en/ publications/Campaignreports/Climate-Reports/GreenwashPlus20/

Buscher, B., Sullivan, S, Neves, K., Igoe, J., \& Brockington, D. (2012). Towards a synthesized critique of neoliberal biodiversity conservation. Capitalism Nature Socialism, 23 (2), 4-30.

Capra, F., \& Henderson, H. (2009). Qualitative growth. London: The Institute of Chartered Accountants in England and Wales.

Castree, N. (2008a). Neoliberalising nature: The logics of deregulation and reregulation. Environment and Planning A, 40, 131-152.

Castree, N. (2008b). Neoliberalising nature: Processes, effects, and evaluations, Environment and Environment and Planning A, 40, 153-173.

Cato, M.S. (2009). Green economics: An introduction to theory, policy and practice. London: Earthscan.

Cato, M.S. (5 September 2012). Reclaiming the green economy. [blog] Retrieved from http://gaianeconomics.blogspot.co.uk/2012/09/reclaiming-green-economy.html Clark, P. (20 June 2012). Rio+20 lacks ambition says UN Chief, Financial Times.

Costanza, R., d'Arge, R., de Groot, R., Farber, S., Grasso, M., Hannon, B., Limburg, K., Naeem, S., O'Neill, R.V., Paruelo, J., Raskin, R.J., Sutton, P., \& van den Belt, M. (1987). The value of the world's ecosystem services and natural capital. Nature. 387, 253-260. 
Common Cause (2014). 2. How values work. [website] Retrieved from: http://valuesandframes. org/handbook/2-how-values-work

Conway, E. (8 August 2009). IMF puts total cost of crisis at £7.1 trillion, The Telegraph. Retrieved from http://www.telegraph.co.uk/finance/newsbysector/ banksandfinance/5995810/IMF-puts-total-cost-of-crisis-at-7.1-trillion.html

Counterbalance (2013). Natural capital: A fairytale with an unhappy ending [blog]. Retrieved from http://www.counterbalance-eib.org/?p=2858

Counterbalance (producer) (2013b, Nov. 21). The great nature sale video [video]. Retrieved from http://naturenotforsale.org/2013/11/27/the-great-nature-sale/

Crompton, T., \& Kasser, T. (2009). Identity campaigning - Meeting environmental challenges: The role of human identity. Godalming, UK: WWF-UK.

Crompton, T. (2010). Common cause. London: WWF-UK.

Crompton, T. (2013, June). Putting a price on the priceless: Valuing nature?

Presentation at Royal Geographical Society, London. [Event] Recording available online, Retrieved from: https://soundcloud.com/britishecologicalsociety/valuingnature-18-june-2013

Daly, H. (2013). The lurking inconsistency. Retrieved from http://steadystate.org/thelurking-inconsistency. An earlier version of this paper appeared in (1999) Conservation Biology, 13 (4), 693-94.

@nickdearden75 (21 Nov 2013). “@andyheald restoring the commons. It's happening: Food sovereignty, community energy, remunicipalise water. Less finance, more regulation." [tweet]. Retrieved from https://twitter.com/nickdearden75/status/403570462925791233

@ nickdearden75 (21 Nov 2013b). "Now \#RioTinto telling us about their net positive impact on the world. That's the beauty of natural capital. \#natcap13 \#notforsale" [Twitter post]. Retrieved from https://twitter.com/nickdearden75/status/ 403523268885639168

DEFRA. (2007). An introductory guide to valuing ecosystem services. London: Department for Environment, Food and Rural Affairs.

Dempsey, J., \& Robertson, M.M. (2012). Ecosystem services: Tensions, impurities, and points of engagement within neoliberalism, Progress in Human Geography, 36(6): 758-779. 
Epstein, G. (2005). Financialization and the world economy. Cheltenham: Edward Elgar.

ETC Group. (2011). Who will control the green economy? ETC Group Communiqué No. 107. Ottawa, Canada: ETC Group.

Fairhead, J. Leach, M., \& Scoones, M. (2012). Green grabbing: A new appropriation of nature?, The Journal of Peasant Studies, 39 (2), 237-261.

Fioramonti, L. (2013). Gross domestic problem. London: Zed Books.

Ford, L. (2012, 21 June). Rio+20 outcome a focal point for frustration among campaigners, The Guardian.

Food and Water Europe (2012, November). And the value of nothing, Alternatives to gross domestic product and the financialisation of nature. Food and Water Europe [website] Retrieved from http://www.foodandwaterwatch.org/briefs /and-thevalue-of-nothing-alternatives-to-gross-domestic-product-and-the-financializationof-nature-2/

Food and Water Europe (2013, November). No accounting for taste: Natural capital accounting and the financialisation of nature. Retrieved from http://www.foodandwaterwatch.org/briefs/and-the-value-of-nothing-alternativesto-gross-domestic-product-and-the-financialization-of-nature-2/

Fuentes-Nieva, R., \& Galasso, N. (2014). Working for the few. Political capture and economic inequality, 178 Oxfam Briefing Paper. Oxfam: Oxford.

Gilbertson, T., \& Reyes, O. (2009). Carbon trading: How it works and why it fails. (Critical Current Dag. No.7). Uppsala: Hammarskjöld Foundation.

Guardian staff \& agencies (2014, 4 January). Campaigners attack proposals to allow destruction of ancient woodlands. The Guardian. Retrieved from http://www.theguardian .com/environment/2014/jan/04/ancient-woodland-cutdown-biodiversity-offsetting

Hanley, N., Shogren, J.F., \& White, B. (2007). Environmental economics in theory and practice. Basingstoke: Palgrave Macmillan.

Jackson, T. (2009). Prosperity without growth? London: Sustainable Development Commission.

Joint Civil Society Statement (June 2012). Ending corporate capture of the United Nations. Rio de Janeiro, Brazil. Retrieved from http://www.foei.org/en/getinvolved/take-action/end-un-corporate-capture 
Kari-Oca 2 Declaration (17 June 2012). Indigenous peoples global conference on Rio+20 and mother earth. Accepted by acclamation, Kari-Oka Village, at Sacred Kari-Oka Púku, Rio de Janeiro, Brazil. Retrieved from http://indigenous4motherearthrioplus20.org/ kari-oca-2-declaration/

Kubiszewski, I., Costanza, R., Franco, C., Lawn, P., Talberth, J., Jackson, T., \& Aylmer, C. (2013). Beyond GDP: Measuring and achieving global genuine progress. Ecological Economics, 93, 57-68.

Lakoff, G. (2009). The political mind. New York: Penguin Books.

Lohmann, L. (2011). Ecosystem services markets: One neoliberal response to crisis. Food Ethics, Summer 2011. Retrieved from www.thecornerhouse.org.uk/sites /...org.uk /.../EcosystemServices.pdf

Lohmann, L. (2012). Beyond patzers and clients: Strategic reflections on climate change and the 'green economy' Development Dialogue. Uppsala: Hammarskjöld Foundation.

Luck, G.W., Chan, M.A., Eser, U., Gomez-Baggethun, E., Matzdorf, B., Norton, B., \& Potschin, M.B. (2012). Ethical considerations in on-ground applications of the ecosystem services concept. BioScience, 62 (12), 1020 -1029.

MacDonald, K.I. \& Corson, C. (2012). 'TEEB begins now': A virtual moment in the production of natural capital. Development and Change, 43 (1), 159-184.

McAfee, K. (2012). The contradictory logic of global ecosystem services markets. Development and Change, 43 (1), 105-131.

Monbiot, G. (2014, 22 April). Can you put a price on the beauty of the natural world? The Guardian. Retrieved from www.theguardian.com/commentisfree/ 2014/apr/22/price-natural-world-agenda-ignores-destroys

Nadal, A. (2012). RIO+20: A citizen's background document. Mexico: Center for Economic Studies, El Colegio de Mexico.

Nature is Not for Sale (Producer) (2013, November 21). Nature not for sale TV. [Livestream/ UStream]. Edinburgh, UK.

Newey, G. (2014, May 13). Monbiot's attacks on biodiversity offsetting are wide of the mark. Business Green. Retrieved from www.businessgreen.com/bg/opinion /2343270/monbiots-attacks-on-biodiversity-offsetting-are-wide-of-the-mark

Nölke, A., Heires, M., \& Bieling, H.J., (2013). Editorial: The politics of financialization. Competition and Change, 17 (3), 209-18. 
Patel, R., \& Crook, M. (2012). At Rio+20, the green economy won't save the planet. But green democracy will. London: Commonwealth Advisory Bureau.

Peck, J. (2010). Constructions of neoliberal reason. Oxford: Oxford University Press.

Peck, J. (2013, July). Explaining (with) neoliberalism. Paper presented at Neoliberalism, Crisis and the World System, University of York, UK.

Roberts, D. (2013, 17 April). None of the world's top industries would be profitable if they paid for the natural capital they use. Grist. Retrieved from http://grist.org/ business-technology/none-of-the-worlds-top-industries-would-be-profitable-ifthey-paid-for-the-natural-capital-they-use

Romero, S., \& Broder, J.M. (2012, 23 June). Progress on the sidelines as Rio conference ends. New York Times.

Schumacher, E.F. (1973). Small is beautiful: A study of economics as if people mattered. Retrieved from www.ee.iitb.ac.in/student/ pdarshan/ SmallIsBeautifulSchumacher.pdf

Scotland Natural Heritage (2012). Scotland's natural capital asset (NCA) Index. Retrieved from http://www.snh.gov.uk/docs/B814140.pdf

Solón, P. (2012). At the crossroads between green economy and rights of nature. Retrieved from http://pablosolon.wordpress.com/2012/06/07/at-the-crossroadsbetween-green-economy-and-rights-of-nature

Spelman, C. (2011). New plans promise flourishing future for the natural environment. 7 June 2011. London: DEFRA.

Stakeholders Forum (2012). Definitions of a green economy. Earth Summit 2012. Retrieved from http://earthsummit2012.org/conference/themes/green-economypoverty-eradication

Strong, M. (1994, 6 June). Asia and a sustainable earth. Lecture to the Asian Development Bank, Manila. Retrieved from http://mauricestrong.net/index.php/speeches-remarks3/34-asia

Sullivan, S. (2012). Banking nature? The spectacular financialization of environmental conservation. Antidote, 45 (1), 198-217.

Sullivan, S. (2013a). Financialisation, biodiversity conservation and equity: Some currents \& concerns. Penang: Third World Network.

Sullivan, S. (2013b). The natural capital myth. Retrieved from http://ppel.arizona.edu/blog/2013/03/15/natural-capital-myth\#_edn5 
TEEB (2010). The economics of ecosystems and biodiversity: Mainstreaming the economics of nature: A synthesis of the approach, conclusions and recommendations of TEEB.

United Nations Environment Programme (2011). Towards a green economy: Pathways to sustainable development and poverty eradication.

UNEP Financial Initiative (2012). Natural capital declaration. Retrieved from http://www.naturalcapitaldeclaration.org/the-declaration/

Vatn, A. (2000). The environment as a commodity. Environmental Values, 9, 493-509.

Vatn, A. (2010). An institutional analysis of payments for environmental services. Ecological Economics, 69, 1245-1252.

Whipple, T. (2012, 29 November). Economists plan to save countryside puts price on nature. The Times. Retrieved from http://thetimes.co.uk/tto/ environment/article3614616.ece

World Forum on Natural Capital (2013, 18th November) Alex Salmond to speak at the World Forum. [blog] Retrieved from http://naturalcapitalforum.com/blog/blog /225/Alex-Salmond-to-speak-at-the-World-Forum

This paper will be published in late March 2015 in the journal Environmental Communication at this link: http://dx.doi.org/10.1080/17524032.2015.1018296 . 